\title{
Evidence of Validity for the Portilho/Banas Teaching Style Questionnaire ${ }^{1}$
}

\author{
Giovani de Paula Batista ${ }^{2}$ \\ Pontificia Universidade Católica do \\ Paraná, Curitiba-PR, Brazil
}

\author{
Evelise Maria Labatut Portilho \\ Pontifícia Universidade Católica do \\ Paraná, Curitiba-PR, Brazil
}

\author{
Sueli Édi Rufini \\ Universidade Estadual de Londrina, \\ Londrina-PR, Brazil
}

\begin{abstract}
The use of instruments with evidence of validity in education research brings advances to the production of knowledge. This article reports the stages of a survey of teaching style and the evidence for its validity. One thousand teachers participated in a study of different levels of education. An exploratory factor analysis indicated a structure of four factors in which 55 items had a factorial load greater than .30 . The correlation steps made it possible to identify how the four factors are related to each other. As a final result, the questionnaire was composed of 40 items, distributed into groups of 10 items organized by teaching style. Evidence of factorial validity and internal consistency of the items that make up the instrument was seen. Analysis of variance indicated that the scale is sensitive to individual differences in the comparison among the four different teaching styles and the gender and teaching level variables.
\end{abstract}

Keywords: scaling (testing), factor analysis, teaching, education, teachers

\section{Evidências de Validade do Questionário Portilho/Banas de Estilos de Ensino}

\begin{abstract}
Resumo: A utilização de instrumentos com evidências de validade para a pesquisa no campo da educação resulta em avanços na produção de conhecimentos. O objetivo deste estudo foi buscar evidências de validade fatorial e consistência interna dos itens que compõem o Questionário Portilho/Banas de Estilos de Ensino. Participaram da pesquisa 1000 professores de diferentes níveis de ensino. A análise fatorial exploratória indicou uma estrutura de quatro fatores, aos quais se agruparam 55 itens com carga fatorial superior a .30. O trabalho de correlação permitiu identificar o quanto os quatro fatores estabelecem relação entre si. Ao final, o questionário ficou composto de 40 itens, distribuídos em 10 para cada estilo de ensino. Foram encontradas evidências de validade fatorial e consistência interna dos itens que compõem o instrumento. A ANOVA indicou que a escala foi sensível a diferenças individuais na comparação entre os quatro estilos de ensino e as variáveis gênero e nível de ensino.
\end{abstract}

Palavras-chave: escalas, análise fatorial, ensino, educação, professores

\section{Evidencias de Validez del Cuestionario Portilho/Banas Estilos de Enseñanza}

\begin{abstract}
Resumen: La utilización de instrumentos con evidencias de validez para investigaciones en el campo de la educación resulta en avances en la producción de conocimientos. La finalidad en este estudio fue conocer evidencias de validez factorial y consistencia interna de los ítems componentes del Cuestionario Portilho/Banas de Estilos de Enseñanza. Participaron de la investigación 1000 profesores de diferentes niveles de enseñanza. El análisis factorial exploratorio indicó una estructura de cuatro factores a los que se agruparon 55 ítems con carga factorial superior a .30. El trabajo de correlación permitió identificar cómo los cuatro factores establecen relación entre sí. Como resultado final, el cuestionario consta de 40 artículos, divididos en 10 para cada estilo de enseñanza. Se observaron evidencias de la validez factorial y consistencia interna de los ítems que componen el instrumento. El ANOVA indicó que la escala era sensible a las diferencias individuales cuando se comparan los cuatro estilos de enseñanza y las variables de género y nivel de educación.
\end{abstract}

Palabras clave: escalas, análisis factorial, enseñanza, educación, profesores

This study describes a literature search on psychometric properties using an instrument assessing teachers' teaching

\footnotetext{
${ }^{1}$ Article based in the master's thesis by the first author under the advice of the second and third authors, defended in 2014 in the Graduate Program in Education at the Pontifícia Universidade Católica do Paraná.

Support: National Council for Scientific and Technological Development (CNPq - Protocol no. 473599/2009).

${ }^{2}$ Correspondence address:

Giovani de Paula Batista. Secretaria de Estado da Educação do Paraná. Rua Araucária, 493, casa 08, Jardim Guraituba. CEP 83410-080. Colombo-PR, Brazil.E-mail: giovanip_batista@hotmail.com
}

style. Evidence of validity was obtained to analyze the accuracy and relevance of a given interpretation proposal; this allowed us to define and determine the type of population that this instrument applies to (Cardoso \& Baptista, 2014; Primi, 2010; Primi, Reppold, \& Gurgel, 2014; Urbina, 2007), as well as to adjust for or even exclude items that, for any reason, do not meet the proposed objective.

We found few pedagogical instruments on teaching styles and no specific assessment measures for this construct. In correlated areas, such as the teacher's motivating style, we identified studies on validity evidence (Figueiredo, 2014; Rufini, \& Boruchovitch, 2004), scales that evaluate teachers' 
views on the quality of student-teacher relationships (Petrucci, Borsa, Barbosa, \& Koller, 2014), studies that identified teachers affected by burnout syndrome (Mallar \& Capitão, 2004), and scales evaluating social skills (Major $\&$ Santos, 2014). Among the studies of theories on teaching style are the studies of Bennet (1979), who defined teaching style as "features revealed in teachers' behavior during classes from his/her interaction with pupils" (p. 27). The emphasis on the behavior also appear in studies by Heimlich and Norland (2002), who defined teaching style as "personal features found in teacher's behavior during his/her classes as a result of a set of beliefs and habits influencing his/her way of thinking and acting" (p. 34). On the basis of the aforementioned studies, teaching style can be defined as a set of attitudes and procedures adopted by teachers that are triggered at each phase of teaching process and highlight a specific manner to conduct classes: i.e., they are particular behaviors the teacher shows when working with students that characterize his/her way of practice.

The most recent studies on teaching style have been shown the need for teachers to employ a variety of approaches to respond to the needs of diverse learners and promote different ways of learning in the classroom (Hernández Valbuena \& Abello Camacho, 2013; Pupo, 2012). These authors highlight the diversity of learners in the classroom, which requires that teachers adopt different ways to conduct classes in order to offer equal learning opportunities to all students. This study sought to identify, using statistical analyses, the elements that indicate evidence of validity of the Portilho/Bana Teaching Style Questionnaire. The aim is to provide teachers with a tool to be used in research situations (in order to enhance knowledge in the area), training, and continuing education of teachers.

\section{Method}

This study for the evidence of the validity of the Portilho/Banas Teaching Style Questionnaire used a correlational and exploratory approach because we did not seek to compare, control or calculate any data, but rather aimed to research evidence of validity of pedagogical instruments with self-report features. Selfreport is a technique that attempts to determine individuals' judgments and statements about themselves. This technique is fundamental to the cognitivist perspective, in which orientation is assumed as conscientious and accessible to the individual. In a given item or hypothetical situation, the participant reports his/her beliefs, indicating the level of correspondence of personal agreement with the construct or subjacent concept (Fulmer \& Frijters, 2009).

\section{Participants}

We included 1,000 teachers (730 women and 270 men aged 19 to 67 years $(M=38.9, S D=9.4)$. Of these, 159 worked in private school, 833 worked in public primary/secondary school and high schools, and 8 worked in institutions of higher education. A total of 167 institutions from the municipality of
Curitiba/Paraná were included (152 state schools, 10 private schools and 5 private higher education institutions). We used a convenience sample (non-probabilistic). Participants in this study were teachers who agreed to answer the questionnaire and those authorized by their institution director/supervisor. Teachers were informed that the study was confidential and that, to dispel any discomfort completing the questionnaire, they could do so without any penalties.

\section{Instrument}

The Portilho/Banas Teaching Style Questionnaire has not been previously validated. This is the first attempt to verify the psychometric validity of this assessment instrument. We evaluated each one of the four teaching styles (dynamic, analytical, systematic, and practical). The assessment had 15 items based on 5-point Likert scale $(5=$ always, $4=$ often, $3=$ sometimes, $2=$ rarely, $1=$ never $)$. As mentioned above, teaching styles are linked to pedagogical procedures used by teachers in the classroom. Teachers' degree of agreement was related to each set of items, or subscales, which corresponded to their personal teaching style. Some examples are as follows: question 3 - "I try to select different teaching strategies for each content area", thought to reflect the dynamic teaching style; question 40 "I use didactic resources that enable students to do detailed analyses of situations", which belongs to the analytical teaching style; question 44 - "I plan my classes foreseeing the control of the class, to avoid discursion", reflecting the systematic teaching style; and question 34 - "I use teaching strategies that promote construction of practical and fast solutions", from the practical teaching style.

\section{Procedure}

The search for evidence of validity of the Portilho/Banas Teaching Style Questionnaire was done in five steps, based on model proposed by Pasquali (2010): application planning, application and collection, dimensionality, instrument precision and establishment of norms. The step referent to application planning is featured by two relevant points: the definition of the sample and instruction on how to apply the instrument. The sample was clearly delimited in terms of its specific characteristics, according to the objective for which the instrument was constructed.

Data collection. Application and information collection for different teaching styles occurred between June and July 2013 following precautions recommended by Pasquali (2010). All participants were accommodated in a given classroom that had been previously scheduled. Mean duration of questionnaire administration was roughly 20 minutes by teachers' group.

Data analysis. Data were coded and transformed to the Stastitic8 Program for planned analyses. To seek evidence of validity of the instrument, a factorial exploratory analysis was done with extraction of main components, internal consistency analysis using Cronbach's alpha and Pearson's correlation. The analysis of variance was used to analyze differences in participants' performance. 


\section{Ethical Considerations}

This study followed national and international ethical and legal aspects of research on human subjects and was approved by the Ethical and Research Committee of the Pontifícia Universidade Católica do Paraná (CAAE no. 03851312.1.0000.0020).

\section{Results}

By using extraction of main components, 32 factors were initially found to correspond to the number of questions in the test. From this procedure, 14 factors appeared with self-value over 1 that explained part of the variability in the total. However, four factors were considered to have higher self-value that corresponded to four subscales with theoretical relevance explaining the variance of $32.6 \%$ of the set. In our analysis, a cut-off point of 30 was established in order to enable the loading of an item to a factor. According to Pasquali (2010), this is an acceptable value, and this would explain at least $9 \%$ of total variance. For this reason, five items of the original structured were excluded; Table 1 (part one and part two) shows the location of each item in the respective factors.

Table 1

Placement of Items With Saturation > 30 in Each of the Four Factors (Part 1)

\begin{tabular}{|c|c|}
\hline & tor 2 Factor 3 \\
\hline
\end{tabular}

1. I plan my class considering the possibility of making changes in the discipline program.

2. I try to make an objective, coherent and structured class plan.

3. I try to select different teaching strategies for each content area.

.46

5. I tend to prioritize teaching strategies with group work.

6. I dedicate more time than planned to work some specific contents.

.54

7. I tend to not follow the planning; I more often improvise.

8. I use teaching strategies that promote constructive discussion.

9. I insist that my students review exercises before handing them back to me.

.44

10. In assessments, I prioritize open-ended and lengthy questions.

.38

.41

11. In assessment activities, I demand well-supported answers.

.62

12. I plan my classes in order to cover all details of the content.

13. I notice that my student learned when he/she masters the logic sequence of content worked.

14. When planning my classes, I seek to articulate theory and practice.

15. I notice that my student learned based on fair results achieved in formal grades.

16. I plan my classes foreseeing chill-out moments of the groups.

17. I plan my classes to provide plenty of time for students to develop experience with content given.

19. I prioritize students' autonomy when they are doing the proposed activities.

20. I plan my classes seeking to give meaning to content according to students' routine.

21. I enable students to discuss the content given.

22. I use discussion as a teaching strategy, but ideas should be based on previous studies.

23. In tests I recommend students to give short, precise and direct answers.

25. I plan my classes prioritizing teaching strategies that favor the detailed analysis of content.

26. I seek to work with content by contextualizing subjects and the author, regardless of the discipline.

27. I give priority to teaching strategies that enable students to search for "reasons" that explain his/her ideas.

28. I plan my classes prioritizing teaching strategies that promote thought.

29. I work with content always integrating it to a broader theoretical milestone.

.33
.54

.45

.53

.58

.44

.52

.59

.55

.35

.54

$32 \quad .35$

$46 \quad .41$

.31

$33 \quad .37$

30. I prefer teaching strategies that promote individual work.

Note. Factor 1 - Dynamic Teaching Style, Factor 2 - Analytical Teaching Style, Factor 3 - Systematical Teaching Style, Factor 4 - Practical Teaching Style. Elaborated by Batista, 2014. 
Table 1

Placement of Items With Saturation > 30 in Each of the Four Factors (Part 2)

\begin{tabular}{|c|c|c|c|c|}
\hline Item & Factor 1 & Factor 2 & Factor 3 & Factor 4 \\
\hline 31. In assessed activities, I promote competitiveness. & & & .44 & \\
\hline 34. I use teaching strategies that promote construction of practical and fast solutions. & & & .54 & \\
\hline 35. I promote discussion of subjects, problems and/or real situations. & .54 & & & \\
\hline 36. I try to not spend too much time with theoretical explanations. & & & .43 & \\
\hline 37. I perceive that my student learned when they study the content outside of the classroom. & & .33 & & \\
\hline 38. I prefer group work in my classes. & .57 & & & \\
\hline 39. I use listening as the basis for thinking about learned subjects. & .51 & & & \\
\hline 40. I use didactic resources that enable students to do detailed analyses of situations. & .39 & & & .37 \\
\hline 41. I use class activities in the classroom that require, from my end, structure and objectivity. & & & & .50 \\
\hline $\begin{array}{l}\text { 42. I prefer, during my classes, activities that enable students to work with observation and } \\
\text { detailing of the proposed subject. }\end{array}$ & & .33 & & .41 \\
\hline 43. In tests, I seek to include fewer questions. & & & .47 & \\
\hline 44. I plan my classes foreseeing the control of the class, to avoid discursion. & & & & .40 \\
\hline 45. I use teaching strategies that promote solving of daily life problems. & .44 & & & \\
\hline 46. In handouts, I try to give clear instructions concerning procedures to be done. & & .34 & & \\
\hline $\begin{array}{l}\text { 47. I never assign another activity until all analysis and arguments of possibilities of the present } \\
\text { topic have ended. }\end{array}$ & & .44 & & \\
\hline 48. During tests, I request that students answer questions in a logical and coherent manner. & & .65 & & \\
\hline 49. In assessment activities, I prefer to elaborate summaries with clear concepts. & & .64 & & \\
\hline 50. I give plenty of time for students to complete tests. & & .47 & & \\
\hline 51. I notice that my student learned when he/she can formulate examples based on the theory. & & .51 & .30 & \\
\hline 52. In tests, I consider it relevant when the student argues about a point of view. & .30 & .48 & & \\
\hline 53. I notice that my student learned when he/she could transfer the content to a practical situation. & .38 & .32 & & \\
\hline 54. In tests, I create questions that require detailed analysis of contents presented in the classroom. & & .55 & & \\
\hline 55. I substitute explanation for practical activities. & .37 & & .46 & \\
\hline $\begin{array}{l}\text { 56. I use teaching strategies that work with experience and activities related to the students' } \\
\text { environment. }\end{array}$ & .60 & & & \\
\hline 57. I stimulate students to participate in presentations and discussions. & 62 & & & \\
\hline 58. In tests, I prioritize practical questions. & & & .60 & \\
\hline 59. In tests, I demand that students answer questions directly and briefly. & & & .58 & \\
\hline 60. I seek to diversify didactic resources used in classes. & .51 & & & \\
\hline
\end{tabular}

Four items - Items 4: "I perceive that my student learned when he/she shows the ability to solve problems", 18: "I plan to begin the year by reviewing content worked on in the previous year", 24: "I notice that my student learned when he/she did good work, showing its practical usefulness", 32: "I notice that my student learned when he/she expressed deep and detailed ideas" and item 33: "I'm not favorable to improvising activities" - did not achieve a factorial load of at least .30 for any factor.

Observing the content of the items grouped around each item of one of the four factors, we found that factor 1 corresponded to the dynamic teaching style subscale, factor 2 corresponded to the analytical teaching style subscale, and factor 3 corresponded to the systematic teaching style subscale, thereby meeting the initial expectation of the learning style questionnaire. From this point on, factors will be mentioned by the corresponding teaching style.

The factorial load analysis related to the four factors showed that some of them loaded simultaneously in more than one factor, indicating that they were not representative to styles that they were originally elaborated and therefore were excluded. This is the case with the following items: item 15 - "I notice that my student learned based on fair results achieved in formal grades," initially thought to belong to the systematic style, which presented a factorial load of .32 for the systematic teaching style and in .34 for 
the analytical style; item 25 - "I plan my classes prioritizing teaching strategies that favor detailed analysis of content", which was originally thought to belong to the systematic style but presented a factorial load of .35 for the analytical style and .54 for the practical style; item 26 - "I seek to work with content by contextualizing subjects and the author, regardless of the discipline", which originally belonged to the systematic style but had a factorial load of .32 for the dynamic style and .35 for the analytic style; item 27 - "I give priority to teaching strategies that enable students to search for 'reasons' that explain his/her ideas", which initially belonged to the systematic style and presented a factorial load of .46 for the dynamic style and .41 for the analytic style; item 28 - "I plan my classes prioritizing teaching strategies that promote thought", which originally belonged to the analytical style and presented a factorial load of .31 in analytical style and .54 for the dynamic style; 29 - "I work with content always integrating it to a broader theoretical milestones", which originally belonged to the dynamic style; item 40 - "I use didactic resources that enable students to do detailed analyses of situations", which originally belonged to the analytical teaching style and presented a factorial load of .39 for the dynamic style and .37 for the practical style; item 42 - "I prefer, during my classes, activities that enable students to work with observation and detailing of the proposed subject", which initially belonged to the analytical style and had a factorial load of .33 for the respective analytical style and of .41 for practical style; item 52 - "In tests, I consider it relevant when the student argues about a point of view", which originally belonged to the analytical style and presented a factorial load of .48 for the teaching style and .30 for the dynamic style; 53 - "I notice that my student learned when he/she could transfer the content to a practical situation", which initially belonged to the practical teaching style and presented a factorial load of load of .38 for the dynamic style and .32 for the analytical style; item 54 "In tests, I create questions that require detailed analysis of contents presented in classroom", originally belonging to the analytical style, which presented a factorial load of .37 for the dynamic style and .46 for the systemic style; and, finally, item 55 - "I substitute explanations for practical activities", which originally belonged to the practical style and presented a factorial load of .37 for the dynamic style and .46 for the systematic style.

Of the 15 items created, item 57 was the most representative for the dynamic teaching style, item 10 had the greatest factorial load for the analytical style, item 43 seemed to be the most representative for the systematic teaching style, and item 2 was the most representative for the practical teaching style. When items loaded in the analytical teaching style, items 25 and 42 also had similar loads in the practical teaching style, but items 28 and 51 had fair factorial load in the dynamic style. In relation to systematic teaching style, of the 15 items created, 48 had greater factorial load for the analytical teaching style, items 18 and 33 did not achieve sufficient factorial load in any factor, item 2 had the greatest factorial load for the practical teaching style and any initial items created for the systematic teaching style had fair factorial load.
Finally, of 15 items created for assessment of factors for the practical teaching style, items $23,34,36,58$, and 59 had great factorial load for the systematic teaching style and item 53 loaded in the dynamic style and analytical style, but items $14,17,20,45,55$, and 56 had great factorial load for dynamic style. Similar to what occurred with the systematic teaching style, no items initially created for the practical teaching style obtained fair load in that factor.

Therefore, the factorial analysis showed that of 55 items that comprised the assessment instrument of teaching styles, 17 belonged to the dynamic teaching style, only 6 belonged to the dynamic and analytical styles, 1 belonged to the dynamic and systematic styles, and 1 belonged to the dynamic and practical styles, totaling 25 items ( $30 \%$ of items that composed the questionnaire). In addition, we observed that 12 items belonged to the analytical teaching style, only 6 belonged to the dynamic and analytical style, 1 belonged to the systematic and analytical styles, and 2 belonged to the analytical and practical styles, totaling 21 items $(21.4 \%$ of questions in the instrument).

In relation to the systematic style, of 55 items that composed the questionnaire, 9 were placed in this factor; among them, 1 also belonged to the dynamic style, 1 to the analytical style, and 1 to the practical style. In the set, they represented $12 \%$, and the lower percentage of items that composed the instrument. In addition, we found 11 items that represented factorial load for the practical style. Among them, 1 also presented fair factorial load for the dynamic style, 2 for the analytical style and 1 for the practical style, explaining, in the set, $16 \%$ of the scale. In addition to exploratory factorial analysis, we searched for evidence of validity by using correlational analysis; results are presented in Table 2.

Table 2

Pearson's Correlation Coefficient Among Means Obtained in the Four Subscales Organized According to Factorial Analysis Results

\begin{tabular}{lcccc}
\hline Variable & Factor 1 & Factor 2 & Factor 3 & Factor 4 \\
\hline $\mathrm{ED}^{1}$ & 1 & & & \\
$\mathrm{EA}^{2}$ & .59 & 1 & & \\
$\mathrm{ES}^{3}$ & .24 & .42 & 1 & \\
$\mathrm{EP}^{4}$ & .51 & .70 & .37 & 1 \\
\hline $\begin{array}{l}\text { Note. } \\
{ }^{1} \text { Dynamic }\end{array}$ & Teaching & Style, ${ }^{2}$ Analytical & Teaching & Style, \\
${ }^{3}$ Systematic Teaching Style, ${ }^{4}$ Practical Teaching Style.
\end{tabular}

In the first analysis, we searched for correlations among four factors configured according to results of the exploratory factorial analysis. As shown in Table 2, we found positive and significant correlations among means obtained by participants in the dynamic style assessment with those obtained in assessment of the analytic style with the practical style; the systematic style had means positively and significantly correlated with the analytical style; and a large positive and significant correlation was found between 
the means obtained in the assessment of the practical style with the dynamic style. In another analysis line, using the analysis of variance test, we sought to compare differences in participants' performance according to personal and socioenvironmental variables, such as sex, formal education, chain of teaching and age.

Table 3

Statistical Data Comparing Means Obtained by Participants in Subscales of Dynamic, Analytical, Systematic and Practical Teaching Style in Relation to Sex

\begin{tabular}{|c|c|c|c|c|c|c|c|c|}
\hline & & & & & & & & \\
\hline & & nale & & & Male & & $F$ & $p$ \\
\hline & $n$ & $M$ & $S D$ & $n$ & $M$ & $S D$ & & \\
\hline $\mathrm{ED}^{1}$ & 729 & 4.02 & .43 & 269 & 3.94 & .47 & 6.44 & .01 \\
\hline $\mathrm{EA}^{2}$ & 729 & 3.93 & .48 & 270 & 3.96 & .46 & 0.83 & .36 \\
\hline $\mathrm{ES}^{3}$ & 729 & 3.07 & .57 & 269 & 3.14 & .57 & 2.74 & .09 \\
\hline $\mathrm{EP}^{4}$ & 730 & 3.93 & .47 & 270 & 3.87 & .49 & 3.07 & .07 \\
\hline
\end{tabular}

Note. ${ }^{1}$ Dynamic Teaching Style, ${ }^{2}$ Analytical Teaching Style, ${ }^{3}$ Systematical Teaching Style, ${ }^{4}$ Practical Teaching Style.

Results presented in Table 3 indicate that a significant difference was found in participants' performance on the dynamic teaching style assessment $(F=6.44, p=.01)$ and sex that revealed large means among women. Table 4 also shows the comparison among means obtained in four subscales and education level variable for teacher work, and we found significant difference in the dynamic teaching style $(F=3.48)$, analytical teaching style $(F=7.70)$ and systematic teaching style $(F=9.14)(p=.00$ for all). Close to these values we found practical teaching style $(F=2.64)$, with a significance level of $p=.02$.

Table 4

Comparison Among Means Obtained by Education Level and Dynamic, Analytical, Systematical and Practical Teaching Style

\begin{tabular}{|c|c|c|c|c|c|c|c|c|c|c|c|c|c|c|c|c|c|c|c|c|}
\hline & \multicolumn{3}{|c|}{$\begin{array}{l}\text { Children's } \\
\text { Education }\end{array}$} & \multicolumn{3}{|c|}{ Primary School } & \multicolumn{3}{|c|}{ High School } & \multicolumn{3}{|c|}{$\begin{array}{c}\text { Primary/High } \\
\text { School }\end{array}$} & \multicolumn{3}{|c|}{ Higher Education } & \multicolumn{3}{|c|}{$\begin{array}{c}\text { Children's } \\
\text { Education/Prima- } \\
\text { ry School }\end{array}$} & \multirow[t]{2}{*}{$F$} & \multirow[t]{2}{*}{$p$} \\
\hline & $M$ & $N$ & $S D$ & $M$ & $N$ & $S D$ & $M$ & $N$ & $S D$ & $M$ & $N$ & $S D$ & $M$ & $N$ & $S D$ & $M$ & $N$ & $S D$ & & \\
\hline $\mathrm{ED}^{1}$ & 4.19 & 77 & .39 & 3.98 & 484 & .42 & 4 & 131 & .49 & 3.99 & 290 & .45 & 3.97 & 8 & .26 & 3.86 & 8 & .2 & 3.48 & .00 \\
\hline $\mathrm{EA}^{2}$ & 3.7 & 77 & .53 & 3.91 & 484 & .48 & 4.01 & 131 & .48 & 4.03 & 291 & .42 & 3.75 & 8 & .32 & 3.68 & 8 & .49 & 7.7 & .00 \\
\hline $\mathrm{ES}^{3}$ & 2.89 & 76 & .55 & 3.04 & 484 & .58 & 3.17 & 131 & .53 & 3.21 & 291 & .54 & 2.3 & 8 & .43 & 3.02 & 8 & .36 & 9.14 & .00 \\
\hline $\mathrm{EP}^{4}$ & 3.85 & 77 & .51 & 3.9 & 484 & .49 & 3.96 & 132 & .47 & 3.95 & 291 & .46 & 3.43 & 8 & .47 & 3.82 & 8 & .45 & 2.64 & .02 \\
\hline
\end{tabular}

Note. ${ }^{1}$ Dynamic Teaching Style, ${ }^{2}$ Analytical Teaching Style, ${ }^{3}$ Systematical Teaching Style, ${ }^{4}$ Practical Teaching Style.

A Tukey analysis indicated that teachers who worked in primary, secondary and high schools simultaneously had higher means in relation to other dynamic styles compared with teachers who worked in college education and children' education and primary education simultaneously (significance level considered was $p<.05$ ). Related to the analytic teaching style, the Tukey analysis revealed significant differences in significance level $(p<.05)$ between those who worked in primary school, high school and primary school and high school, simultaneously.

Results also pointed out significant differences in performance in the assessment of the analytical teaching style; the same was observed for the dynamic style. Concerning the systematic teaching style, in addition to these four levels, this analysis showed significant differences in higher education; however, the Tukey test did not reveal statistically significant differences among teachers who worked in children's education and primary education.

The fact that Tukey analysis shows that teachers from different teaching levels prioritize the dynamic, analytical and systematic styles that is one more clue of validity evidence, particularly because this finding is close to the theory it supports. However, this analysis did not determine significant differences concerning the practical teaching style and education levels, showing causality between this variable and teaching style. Regardless of the arbitrariness in the choice of indices, starting from 5\% to indicate significant differences avoids statistical errors to a reasonable extent (Rufini \& Boruchovitch, 2004). This finding leads us to the hypothesis of correlation occurring in a casual manner 
as the one that occurred with professors who worked with children's education and primary education in relation to the systematic style. We emphasize that the results presentation in the analysis can vary in many participants because some of them left one or more items blank.

\section{Discussion}

This study sought to determine evidence of factorial validity and internal consistency of items making up the Portilho/Banas Teaching Style Questionnaire. Statistical analyses identified four main teaching styles (dynamic, analytical, systematic and practical), and the coefficients of internal consistency of assessment subscales (Cronbach's alpha coefficient) are above the cutoff point often recommended (.70) (Bzuneck \& Guimarães, 2003; Fontes \& Azzi, 2012; Leal, Miranda, \& Carmo, 2012; Reeve, Bolt, \& Cai, 1999). However, it is prudent to emphasize that our study is the first to seek evidence of validity using the Portilho/ Banas Teaching Style Questionnaire; for this reason, further studies are warranted to refine this instrument. Bearing this qualification in mind, the main findings will be discussed.

After the analysis of main components, we opted to keep four factors that obtained higher self-value meeting the initial expectation for Portilho/Banas Teaching Style Questionnaire version. The first one was the dynamic teaching style, followed by the analytical, the systematic, and the practical teaching styles. In particular, the dynamic teaching style referred to behaviors of the teacher who, during classes, did not always follow a planned content schedule but instead preferred to create space for real discussions, favoring collaborative work with students and opting to work with broader questions. However, the analytical teaching style is used by teachers who week to impart all content in detail, invest more time than planned with specific content, and give students time to review the content.

The systematic teaching style revealed a teaching practice that prioritizes the coherence and structure of working content by using teaching strategies that promote debate and incentivize the creation of supported answers from students. Finally, the practical teaching style is present among teachers who reserve time for students to experience the learned content, who seek teaching strategies that promote construction of practical and fast solution and who opt to work in class with problems from students' routine (Banas, 2013). The correlation analysis between performance in assessment of the four teaching styles indicated positive and significant correlation between analytical and practical styles, a result that indicated correspondence between the content of the two subscales or between the two constructors. For the others, correlations were weak and moderate, which indicate that they were different constructors.

As a complement, by using analysis of variance, we could verify the sensibility of the instrument to catch individual differences; identifying a high score among women for the dynamic teaching style suggested that in their practice they tend to prioritize students' autonomy to solve activities, to use group work, and to promote competition and activities involving broader issues. We could perceive the presence of the four teaching styles in children' education, primary education, high school education and college education. After the analyses were done, we observed that the systematic and practical teaching styles had fewer items than the dynamic and analytical teaching styles. Therefore, of 60 initial items in the instrument, after the performance of steps suggested in the literature, we opted to keep those that showed better representativeness of teaching styles based on factorial loads. As the final result, the Portilho/Banas Teaching Style Questionnaire was composed of 40 items, distributed in 10 items for each teaching style (dynamic, analytical, systematic and practical).

The several analyses performed in this study indicated evidence of the validity of the Portilho/Banas Teaching Style Questionnaire. With the exception of items 4, 18, 24, 32 and 33 , the other items are coherent with the theoretical proposition that support and show the acceptable psychometrical proprieties. Researchers in the area of teaching styles will have a new assessment instrument available to be used with other samples in order to refine thoughts in this area. In addition, this represents a contribution that deepens the theoretical basis. Educational implications of teaching styles are an important and a topical issue. Studies are warranted to expand the knowledge in the area and enhance assessment instruments.

\section{References}

Batista, G. P. (2014). Survey evidence validity of an educational instrument (Master's thesis). Retrieved from http://www.biblioteca.pucpr.br/tede/tde_busca?arquivo. php? $\operatorname{cod}$ Arquivo $=2801$

Cardoso, H. F., \& Baptista, M. N. (2014). Escala de Percepção do Suporte Social (versão adulta) - EPSUS-A: Estudo das qualidades psicométricas [Scale of Perceived Social Support (adult version) - EPSUS-A: Study of psychometric qualities]. Psico-USF, (Bragança Paulista), 19(3), 499-510. doi:10.1590/1413-82712014019003012

Banas, J. C. B. (2013). Styles of teacher education: A pedagogical instrument construction (Master's thesis). Retrieved from http://www.biblioteca.pucpr.br/tede/tde busca/arquivo.php?codArquivo $=2655$

Bennet, N. (1979). Estilos de ensenãnza y progreso de los alumnos [Teaching style and progress of students]. Madrid, Spain:Morata.

Bzuneck, J. A., \& Guimarães, S. E. R. (2003). Crenças de eficácia de professores: Validação da escala de Woolfolk e Hoy [Teachers' efficacy beliefs: Woolfolk \& Hoy's scale validation]. Psico-USF, 8(2), 137-143. doi:10.1590/ S1413-82712003000200005

Figueiredo, E. A. F. (2014). Controle ou promoção de autonomia? Questões sobre o estilo motivacional do professore o ensino do instrumento musical [Controlling or autonomy support? Issues about teachers' motivational style and instrumental music teaching]. Revista da Abem, 22(32), 77-89.

Fontes, A. P., \& Azzi, R. G. (2012). Crenças de autoeficácia 
e resiliência: Apontamentos da literatura sociocognitiva [Self-efficacy beliefs and resilience: Findings of social-cognitive literature]. Estudos de Psicologia, (Campinas), 29(1), 105-114. doi:10.1590/S0103166X2012000100012

Fulmer, S. M., \& Frijters, J. C. A. (2009). A review of selfreport and alternative approaches in the measurement of student motivation. Educational Psychology Review, 21(3), 219-246. doi:10.1007/S10648-009-9107-x

Heimlich, J. E., \& Norland, E. (2002). Teaching style: Where are we now? New Directions for Adult and Continuing Education, 2002(93), 17-26. doi:10.1002/ace.46

Hernández Valbuena, C., \& Abello Camacho, D. M. (2013). Los estilos de enseñanza de los docentes de la licenciatura en educación con énfasis en educación especial de la Universidad Pedagógica Nacional [Teaching styles of teachers in the education degree with special education emphasis from the Universidad Pedagógica Nacional]. Revista Colombiana de Educación, 64, 309-325. Retrieved from scielo.org.co/pdf/rcde/n64/n64a13.pdf

Leal, E. A., Miranda, G. J., \& Carmo, C. R. S. (2011). Teoria da autodeterminação: Uma análise da motivação dos estudantes do curso de ciências contábeis [Selfdetermination theory: An analysis of student motivation in an accounting degree program]. Revista Contabilidade \& Finanças, 24(62), 162-173. doi:10.1590/S151970772013000200007

Major, S., \& Seabra-Santos, M. J. (2014). Preschool and Kindergarten Behavior Scales - second edition (PKBS-2): Adaptação e estudos psicométricos da versão portuguesa [Preschool and Kindergarten Behavior Scales - second edition (PKBS-2): Adaptation and psychometric studies of the portuguese version]. Psicologia Reflexão e Crítica, 27(4), 689-699. doi:10.1590/1678-7153.201427409

Mallar, S. C., \& Capitão, C. G. (2004). Burnout e hardiness: Um estudo de evidência de validade [Burnout and hardiness: A study of evidence of validity]. Psico-USF, 9(1), 19-29. doi:10.1590/S1413-82712004000100004

Pasquali, L. (2010). Instrumentação psicológica: Fundamentos e práticas [Psychological instrumentation: Bases and practices]. Porto Alegre, RS: Artmed.

Petrucci, G. W., Borsa, J. C., Barbosa, A. J. G., \& Koller, S. H. (2014). Adaptação cultural e evidências de validade da Escala de Relacionamento Professor-Aluno [Cultural adaptation and evidences of validity of the StudentTeacher Relationship Scale]. Avaliação Psicológica, 13(1), 133-142. Retrieved from http://pepsic.bvsalud.org/ pdf/avp/v13n1/v13n1a16.pdf

Primi, R. (2010). Avaliação psicológica no Brasil: Fundamentos, situação atual e direções para o futuro [Psychological assessment in Brazil: Foundations, current situation and future directions]. Psicologia: Teoria $e$ Pesquisa, 26(Special issue), 25-35. doi:10.1590/S010237722010000500003

Pupo, E. A. (2012). Los estilos de enseñanza, una necesidad para la atención de los estilos de aprendizaje en la educación universitária [The styles of teaching, a necessity for the attention of the styles of learning in university education]. Revista Estilos de Aprendizaje, 10(10), 79-87. Retrieved from http://www.uned.es/revistaestilosdeaprendizaje/ numero_10/articulos/Articulo07.pdf

Reeve, J., Bolt, E., \&Cai, Y. (1999). Autonomy-supportive teachers: How they teach and motivate students. Journal of Educational Psychology, 91(3), 537-548. doi:10.1037/0022-0663.91.3.537

Reppold, C. T., \& Gurgel, L. G. (2014). O processo de construção de escalas psicométricas [The process of construction of psychometric scales]. Avaliação Psicológica, 13(2), 307-310. Retrieved from http:// pepsic.bvsalud.org/pdf/avp/v13n2/v13n2a18.pdf

Rufini, S. E., \& Boruchovitch, E. (2004). O estilo motivacional do professor e a motivação intrínseca dos estudantes: Uma perspectiva da teoria da autodeterminação [Teacher's motivational style and students' intrinsic motivation: The self-determination perspective]. Psicologia: Reflexão e Crítica, 2004, 17(2), 143-150. doi:10.1590/S010279722004000200002

Urbina, S. (2007). Fundamentos da testagem psicológica [Essentials of psychological testing]. (C. Dornelles, Trans.). Porto Alegre, RS: Artmed.

Giovani de Paula Batista is a Ph.D. candidate of the Graduate Program in Education at Pontifícia Universidade Católica do Paraná.

Evelise Maria Labatut Portilho is a Full Professor at Pontifícia Universidade Católica do Paraná.

Sueli Édi Rufini is an Associate Professor at Universidade Estadual de Londrina.

Received: Dec. 9, 2014

1st Revision: Apr. 13, 2015

Approved: May 12, 2015

How to cite this article:

Batista, G. P., Portilho, E. M. L., \& Rufini, S. É. (2015). Evidence of validity for the Portilho/Banas Teaching Style Questionnaire. Paidéia (RibeirãoPreto), 25(62), 317-324. doi: 10.1590/1982-43272562201505 